\title{
THE SCOPE OF THE INITIATIVE AND REFERENDUM IN CALIFORNIA
}

\begin{abstract}
And while I do not by any means believe the Initiative, the Referendum, and the Recall are the panacea for all our political ills, yet they do give to the electorate the power of action when desired, and they do place in the hands of The People the means by which they may protect themselves.
\end{abstract}

$$
\text { -Hiram Johnson }{ }^{1}
$$

The initiative and referendum are direct legislative devices which were instituted in California and some twenty-one other states as part of the Progressive reform program during the early $1900{ }^{\prime}$ s. $^{2}$ Most citizens recognize these devices as the lengthy legislative propositions which appear on the ballot at every election-although, technically, niost of those which appear are not true initiatives or referenda. ${ }^{3}$ Many attorneys, while perhaps knowing nore about the initiative and referendum, may be equally unaware of some of the effects these institutions can have upon them as citizens and, perhaps of more importance here, $m$ their professional lives. For example, to know that a measure enacted by the initiative may have a special status and prevail over conflicting measures enacted by ordinary procedures inight prove extremely useful. ${ }^{4}$ The same

1 Inaugural Address, January 4, 1911, in HickBord, StORY of THE SEsston of THE CactForNIA LegtsLature of 1911, at 93 n.115 (1911).

${ }^{2}$ See Note, 3 Stan. L. Rev. 497, 497-99 (1951); Casstevens, Reflections on the Initiative Process in California State Politics, Public Affairs Report, Bulletin of the Institute of Governmental Studies, University of California, Berkeley, Vol. 6, No. 1, Feb. 1965, p. 1 [hereinafter cited as Casstevens]. See generally CRoucr, The INITIATIVE aNd ReFERENDUM in Catreornta (1950); Hofstadter, The Age of Reforar: From Bryan to F.D.R. 254-55, 258-59, 265-66 (1955); HYinK, Brown \& Thacker, Politics and GovernMant IN CaIIFORNIA 90-107 (4th ed. 1965); OBERHOLTZER, THE REFERENDUM IN AMERICA (1912); The Initiative, Referendum and Recall, 43 Annals 3-215 (1912).

3 Of seventy-five measures presented in the last four general elections, six were bond measures required to be on the ballot by one statute or another (see, e.g., CaI. Const. art. XVI, § 1; CAI. Gov'T CODE $\S 43608$ ), and fifty-six were constitutional amendments passed by the legislature (CAI. Const. art. XVIII, § 1). Statistics compiled from Jordan, CaIIrorNIA Statemient of Vote, General Election, Nov. 3, 1964, at 22-27; Jordan, Proposed AMrendments to Constitution, General Election, Nov. 6, 1962, at 3-34; Jordan, Caltrornda Statearent of Vote, Generax Election, Nov. 8, 1960, at 23-30; Jordar, Californda Statemente of Vote, Generar Election, Nov. 4, 1958, at 26-34.

${ }^{4}$ CaI. Const. art. IV, \& 1 (II 9) states: "[N] o act, law or amendment to the Constitution, adopted by the people at the polls under the initiative provisions of this section, sball be amended or repealed except by a vote of the electors, unless otherwise provided in said initiative measure ...." See also CaI. Const. art. IV, \& $1 \mathrm{~b}$.

See Cax. Elect. Code $\S 3720$ (counties); Cax. Elect. Code $\S 4015$ (cities); Cac. Elect. CODE $\S 5162$ (special districts). Note that the statutes purport to give blanket immurity to all indirect initiatives (see text accompanying notes 16-19 infra), while the constitution protects only those measures adopted "at the polls." At the state level, then, an indirect initiative measure adopted by the legislature could be freely amended. 
may be true of knowing that, as a consequence of the referendum, legislation does not ordinarily become effective immediately upon passage. ${ }^{\sigma}$ Both of these by-products of direct legislation may have practical ramifications in legal contexts not normally associated with the initiative and referendum. ${ }^{6}$ Furthermore, in a proper situation, the initiative or referendum may serve as a tool for accomplishing client objectives or, in a manner especially appropriate to one trained in the law, for fulfilling one's responsibilities as a citizen. ${ }^{7}$

The desirability of the initiative and referendum as institutions is a political question still actively raised from time to time..$^{8}$ One would thimk, however, that not even the staunchest of judicial activists would suggest that the continued existence of the initiative and referendum should be a matter for judicial determination. Yet, the decisions in some initiative and referendum cases have diminished these devices to an unnecessary degree. This Comment will explore the scope of the initiative and referendum and the extent of the inroads upon them.

5 CaL. Const. art. IV, $1(\llbracket \pi 5,7)$ (no earlier than 90 days after adjournment of legislature); Cal. Elect. Code $\$ \S 3751-52$ (county-30 days); Cal. Elect. Code $\$ \$ 4050-51$ (city-30 days); CAL. ELECT. CoDE $\$ 5200$ (special district-30 days); e.g., Charter of the City and County of San Francisco $\$ 179$ (60 days); Oakland City Charter $\$ 178$ (60 days).

${ }^{6}$ Exemplary of cases not involving initiatives but turning on the special status of initiated laws are Gamble v. Board of Osteopathic Examiners, 21 Cal. 2d 215, 130 P.2d 382 (1942) (statute regulating osteopaths attacked as conflicting with initiated statute); Beneficial Loan Soc'y, Ltd. v. Haight, 215 Cal. 506, 515, 11 P.2d 857, 860-61 (1932) (Personal Property Brokers Act conflicted with initiated usury statute); Pcople v. Schuster, 122 Cal. App. Supp. 790, 793, 10 P.2d 204, 206 (1932) (chiropracter's conviction reversed, law invalid because conflicted with initiated statute).

Demonstrative of the relevance of the referendum-created incubation period (see note 5 supra) in contexts where no referendum is at issue are County of Fresno v. Brix Estate Co., 194 Cal. 85, 226 Pac. 77 (1924) (lien invalid because county acted before 90 days had passed); In re Newell, 188 Cal. 762, 207 Pac. 371 (1922) (emergency deelaration invalid, measure not in effect when petitioner arrested); In re MeDermott, 180 Cal. 783, 183 Pac. 437 (1919) (emergency measure, conviction upheld); Azevedo v. Jordan, $237 \mathrm{Cal}$. App. 2d 521, $47 \mathrm{Cal}$. Rptr. 125 (1965) (right to be delezate at political meeting); In re Stratham, 45 Cal. App. 436, 187 Pac. 986 (1920) (emergency measure, conviction upheld); Rigdon v. City of San Diego, 30 Cal. App. 107, 157 Pac. 513 (1916) (grant of liquor license blocked, 30 days bad not passed); McClure v. Nye, 22 Cal. App. 248, 133 Pac. 1145 (1913) (state officials denied appropriations).

7 This may especially be true on the local level where the signature requirement would be less prohibitive and where the need for or utility of these devices would likely be greater.

${ }^{8}$ See Casstevens, pp. 2-3. For a view of the general policy debate, see In re Pfahler, 150 Cal. 71, 88 Pac. 270 (1907) (dissent) (mob rule); Crouch, The INItIATTVE AND ReFerendum IN CALIFORNIA (1950) (initiative and referendum work well in practice); Campbell, The Initiative and Referendum, 10 MicE. L. REv. 427 (1912) (dangers and defects of direct democracy); Radin, Popular Legislation in California: 1936-1946, 35 CALF. L. Rev. 171 (1947) (work well in practice); Sclwartz, Initiative Held in Reserve, 41 NaT'c MunNc. Rev. 142, 143 (1952) (useful against rural dominated legislatures); Smith, Can We Afford the Initiative?, 38 NAT'工 MoNxc. REv. 437 (1949) (long ballot, measures reflect special interests). 
I

THE INITIATIVE AND REFERENDUM IN GENERAL

The initiative and referendum may be used to enact or to challenge most legislative measures, either in whole or in part. ${ }^{9}$ Each device provides a means for obtaining a popular vote on a given issue-the initiative for proposmg legislation and the referendum for attacking legislation newly enacted. Normally, each requires the circulation of petitions ${ }^{10}$ and the securing of a specified number of qualified electors' signatures ${ }^{11}$ to bring a question to a vote. Yet while these devices have numerous similarities and are often mentioned together or interchangeably, one should take care not to confuse them ${ }^{12}$ as some judicial dicta seem to have done. ${ }^{13}$

\section{A. Terminology}

Essentially, there are two types of initiative and three types of referendum. ${ }^{14}$ The direct initiative operates as an independent method of

${ }^{\circ}$ CAL. Const. art. IV, $\$ 1$ (II 1 ). Sections or parts of an act are referrable at all levels. See Dye v. City of Compton, 80 Cal. App. 2d 486, 182 P.2d 623 (1947).

10 Circulation of petitions may not continue indefinitely but is subject to specified limitations. This is necessarily true as regards the referendum since the attacked measure will go into effect if a petition is not filed within the mcubation period. See statutes cited note 5 supra. But limits are similarly imposed on the circulation of petitions for an initiative. See Gage v. Jordan, 23 Cal. 2d 794, 147 P.2d 387 (1944); CAL. Const. art. IV, § 1 (I 4); CAI. Elect. Code $\$ 3706$ (counties); Cax. Elect. Code $\$ 4007$ (cities). But see Cat. Elect. Code $\$ \S 5150-5201$ (special districts).

11 At the state level, the direct initiative (see text accompanying note 15 infra) requires $8 \%$ and the referendum and indirect initiative eacl require $5 \%$ of the total votes cast for candidates for governor at the preceding gubernatorial election. CAL. ConsT. art. IV, \& 1 (III 3, 4, 7). Through 1966 this meant, in absolute terms, 468,259 and 292,662 signatures respectively. Jordan, Caxirornta Statearent of Vote, Generai Euecrion, Nov. 6, 1962, at 36. Professional petition circulators may charge twenty-five cents or more per siguature; hence getting a petition circulated could prove extremely expensive. See Casstevens, p. 2; Smith, supra note 8 , at 441 .

12 The referendum, for example, may not be used to secure a vote on an emergency measure, but the imitiative may be available to repeal the incasure. See State ex rel. Sharpe v. Hitt, 155 Ohio St. 529, 99 N.E.2d 659 (1951). Also, while the initiative may not be available when special procedures are required for the adoption of a measure, the referendum may still be used after the measure is passed. Compare Hurst v. City of Burlingame, 207 Cal. 134, 277 Pac. 308 (1929) with Dwyer v. City of Berkeley, 200 Cal. 505, 253 Pac. 932 (1927), and Johnston v. City of Claremont, 49 Cal. 2d 826, 323 P.2d 71 (1958). But see Mueller v. Brown, 221 Cal. App. 2d 319, 34 Cal. Rptr. 474 (1963) (administrative acts beyond scope of both); Starbuck v. City of Fullerton, 34 Cal. App. 683, 168 Pac. 583 (1917) (neither initiative nor referendum available for matters of non-general concern) (dictum).

${ }^{13}$ Alexander v. Mitchell, 119 Cal. App. 2d 816, 827, 260 P.2d 261, 267 (1953) (since ordinance cannot be repealed by referendum, it cannot be repealed by initiative) (dictum); Cliase v. Kalber, 28 Cal. App. 561, 573-74, 153 Pac. 397, 402 (1915) (initiative would deprive owners of right to liearing, likewise referendum) (dictum).

14 The categorization which follows appears in Fordham \& Prendergast, The Initiative and Referendum at the Municipal Level in Ohio, 20 U. CINc. I. Rev. 313, 316-18 (1951). 
legislating by by-passing the legislature entirely and placing a measure directly on the ballot at either a special election or a subsequent regular election. ${ }^{15}$ The indirect initiative, which is the only type available in general law cities and counties ${ }^{16}$ and which requires fewer signatures to quahify at the state level, ${ }^{17}$ entails submission of the measure to the legislative body which must then enact the measure within a specified period of time ${ }^{18}$ or, failing to do so, must submit it to the voters at the next election or at a special election. ${ }^{19}$ Along with the initiated measure the

Admittedly, differing categorizations could be made. See Crouch, The Initiative and Referendum in Cities, 37 AMr. PoL. ScI REv. 491, 492 (1943) (making fourth category of advisory referendum); Casstevens, p. 2 (adding initiated constitutional amendments).

15 CaL. Const. art. IV, $\S 1$ (匹 3 ).

10 CaL. Elect. Code $\$ \S 3708,3711$ (counties); Cal. Elecr. Code $\$ \S 4011-12$ (cities). See also CAL. ELECT. Code $\$ 5153$ (special districts).

There are three types of cities in California: general law cities, charter cities and cities created by special legislative enactment before the adoption of the state constitution. Essentially, the difference between general law cities and charter cities is that the former are governed by general state law, and hence by the sections cited above, while the latter have as their organic law charters adopted by the local citizens and approved by the legislature. Cat. Const. art. XI, §§ 6, 8; Comment, 36 So. CaL. I. Rev. 430-31 (1963). A charter provision or a city ordinance authorized under a charter provision may vary the general law and prevail over it when the subject is an exclusively municipal concern. CAI. CoNST. art. XI, § 8(j); Note, 53 CALIF. L. REv. 902, 908 (1965). Charter counties have similar autonomy. CAI. Const. art. XI, \& 71 2 ; Pearson v. County of Los Angeles, 49 Cal. 2d 523, 536, 319 P.2d 624,632 (1957). Cities created by special legislative enactment are governed under that legislation. Conment, 36 So. CAL. L. REv. 430 n.4 (1963).

17 See note 11 supra.

18 If the measure is enacted by the legislature, it is subject to the ordinary referendum machinery. CAI. CoNsT. art. IV, \& I (II 4).

19 See Cal. Const. art. IV, \& I ( $(\mathbb{4} 4)$; Cal. Elect. Code $\$ 3708$ (counties); Cal. Elect. CODE $\S 4011$ (cities). The statewicle indirect initiative has been used but four times since 1912 and would be eliminated entirely by a revision of article IV of the constitution which will appear on the Noveniber ballot. West's CaLtrornda LegisLative Service 416-17, 424-25 (1966); California Constrtutiost Revision Commassion, Proposed Revision of the CaIfrornia Constitution 52, 141-42 (1966) [hereinafter cited as Constitution Revision Conanission]. For further discussion of the revision see note 29 infra. A possible explanation for the failure of persons to take advantage of the lower signature requirement for indirect initiatives may be the extreme delay which stands between the completion of signature gathering and final submission of the neasure to the voters. Unless the governor should call a special election, a minimum of approximately 23 months passes before an indirect initiative is placed on a ballot. This delay results because the indirect initiative procedure calls for submission of the proposed measure to the legislature before it convenes (CAL. Const. art. IV, § 1 (II 4)); the legislature convenes for general legislative sessions in January of every odd numbered year (CAL. CoNsT. art. IV, \& 2 (a)); the measure, if not enacted within 40 days, must be presented at the ensuing general election (CAL. CoNsT. art. IV, \& I ( $\llbracket 4$ ), but that general election does not come until Noveniber of the next even numbered year (CAL. Const. art. IV, § 3). Under the proposed revision of article IV, the legislature would hold annual legislative sessions (Construtron Revision Cosanssion 29-30), and, if the indirect initiative were retained, it might become a more viable tool. The period of delay could be reduced to as bittle as 10 months and a few days. Staff Memorandum for California Constitution Revision Commission, January 12, 1965, p. 11. 
legislature may also submit to the people an alternative proposal of its own. ${ }^{20}$

The compulsory referendum serves as an automatic check on legislation by requiring voter approval of certain measures, such as amendments to initiative enactments, ${ }^{21}$ before they can take effect. The optional referendum is the traditional type whereby the people may petition to require submission of a newly enacted measure to a popular vote. ${ }^{22} T_{\text {wo }}$ varieties are found. At the state level, the measure is placed directly on the ballot, ${ }^{23}$ while at the local level, excepting charter cities where appropriate, ${ }^{24}$ the legislative body is given an opportunity to repeal the measure in order to avoid the public vote (and consequent expenses), referral being mandatory if it fails to do so. ${ }^{25} \mathrm{~A}$ third type of referendum, the voluntary referendum, permits a specified number of legislators to refer a measure to a public vote. ${ }^{26}$ The public vote binds the legislative body which must act accordingly. ${ }^{27}$ Unless otherwise noted, further references in this Comment to the "initiative" and "referendum" will include both the indirect and direct initiatives but only the optional referendum.

\section{B. Constitutional Framework}

The basic law of the initiative and referendum, whicl applies equally at all levels of government, ${ }^{28}$ is set down in detail in article IV, section 1 of the state constitution. ${ }^{29}$ It vests the legislative power of the state in

${ }^{20}$ Cax. Const. art. IV, $\S 1$ (II 4). See Car. Elecr. Code $\$ \$ 3750$ (counties), 4019 (cities), 5201 (special districts). This opportunity for submission of an alternative measure, giving the voters a choice, is thought by some to make the indirect more desirable than the direct initiative. See Smith, supra note 8 , at 442 . Local legislative bodies, however, seldom take advantage of this feature. See Crouch, The Initiative and Referendum in Cities, 37 AMr. Por. Scr. REv. 491, 497 (1943).

21 See note 4 supra.

22 It normally operates by suspending the effective date of a measure. See statutes cited in note 5 supra.

23 CaL. Const. art. IV, \& 1 (II 7).

24 See note 40 infra and accompanying text.

25 CAL. Elect. Code $\$ \$ 3752-53$ (counties and special districts by $\S 5200$ ); Car. ELECT. Cope $\$ \$ 4051-52$ (cities). See also e.g., Charter of the City and County of San Francisco $\S 179 ;$ Oakland City Charter $\$ 178$.

${ }^{26}$ See Cax. Elect. Code $\S 3750$ (counties); CaL. Elect. Code $\S 4019$ (cities); Cax. EuEcr. Code \& 5201 (special districts). See also Charter of the City and County of San Francisco § 179; Oakland City Charter $\S 179$; Charter of the City of Los Angeles $\S 269$. San Francisco's provision allows referral by the mayor or by one-third of the board of supervisors in addition to the referral by a majority of legislators allowed by these other provisions.

27 See statutes cited note 26 supra. See 31 Ops. CaL. Atry. Gen. 100 (1958); Charter of the City and County of San Francisco $\$ 179$.

28 See Dye v. City of Compton, 80 Cal. App. 2d 486, 489, 82 P.2d 623, 625 (1947); Brown v. Boyd, 33 Cal. App. 2d 416, 91 P.2d 926 (1939).

29 A proposed revision of article IV, part of a program to eliminate dead weight from 
the legislature while reserving to the people "the power to propose laws and amendments to the Constitution" and "to . . . adopt or reject any act, or section or part of any act, passed by the Legislature." ${ }^{" 30}$ Unpleasant practical experiences with the initiative produced sections 1a through 1d of article IV, which make agencies created by the initiative subject to the budgetary law, authorize the legislature to enact amendments to initiated measures which will be effective if approved by the voters, ${ }^{31}$ limit initiative measures to one subject, ${ }^{32}$ and prohibit the naming of individuals to office. ${ }^{33}$ An amendment ${ }^{34}$ prohibiting legislation from designating a private corporation to perform any function was approved by the voters in $1964 .^{35}$ Acts calling elections or providing for tax levies or

the constitution and to make it into the basic instrument of government which a constitution ought to be, was before the legislature during its special session this year and will appear for voter approval on the November ballot. West's CAIIFORNIA LeGisLatrve SERvice 416-17, 424-25 (1966). If adopted, the revision would reorganize the existing constitutional provisions dealing with the initiative and referendum into distinct and more logical sections. Constrtution Revision Comanssion 7, 23, 43-50.

For the most part, the alterations are in language and phraseology; only a few, minor substantive changes are proposed. Of most significance would be the elimination of the indirect initiative at the state level and the reduction of the signature requirement for the direct initiation of statutes from 8 to $5 \%$ of the total votes for gubernatorial candidates at the last gubernatorial election. The requirement for initiation of constitutional amendments would remain at $8 \%$. Id. at $23,43-44$.

This change is proposed because the indirect initiative has been so seldom used (see note 19 supra) and hecause it is hoped to encourage electors to propose statutory measures as statutes rather than as constitutional amendments. $I d$. at 23,44 . Under the present law, with no differentiation between the requirement for direct initiation of statutes and constitutional amendments, there is a built-in inducement to propose a measure as a constitutional amendment since the same signature requirement applies and since a constitutional amendment will be less susceptible to a charge that it is unconstitutional under the state constitution. See McFadden v. Jordan, 32 Cal. 2d 330, 196 P.2d 787 (1948), cert. denied, 336 U.S. 918 (1949).

30 CaL. Const. art. IV, $\$ 1$ ( $\llbracket 1$ ).

31 Compare CaI. Const. art. IV, $\$ 1$ ( $\mathbb{I} 9)$. There had been some doubt, as the constitution stood, as to whether and by what procedure the legislature might amend initiated measures. See Beneficial Loan Soc'y, Ltd. v. Haight, 215 Cal. 506, 515, 11 P.2d 857, 861 (1932); Jordan, Proposed Amendments to Constitution: Tocether With Arouments, Generar Election, Nov. 5, 1946, at 12-13. The amendment settled that the legislature may enact amendments to initiated measures to become effective if approved by the voters.

32 This restriction appears prompted by the ommibus constitutional amendment held invalid as an attempted revision of the constitution in McFadden v. Jordan, 32 Cal. 2d 330, 196 P.2d 787 (1948), cert. denied, 336 U.S. 918 (1949).

33 This restriction was prompted by a pension measure passed in 1948 which designated the new director of social welfare. See Casstevens, p. 2.

34 CaI. Const. art. $T V, \S 1 d$ (b).

35 This restriction was prompted by a lottery measure, appearing on the same 1964 ballot, which named a private corporation to manage the lottery. The lottery measure, however, was defeated. Jordan, California Statement of Vote, Generax Election, Nov. 3 , 1964, at 25. If both measures had passed, the one receiving the largest affirmative vote would have prevailed. CAI. Const. art. IV, \& 1 (II 10). 
appropriations for usual current expenses ${ }^{36}$ and urgency measures passed by a two-thirds vote of both houses of the legislature are expressly exempted from the referendum. ${ }^{37}$ However, no measure creating or abohishing an office, or changing the salary, term, or duties of an officer, or granting a franchise, special privilege, or vested right may be passed as an urgency measure. ${ }^{38}$

Article IV, section $1^{39}$ further reserves the initiative and referendum to the people at the city and county levels of government. For governmental entities of the same kind, the scope of the initiative and referendum is the same, except in the rare instance where a city charter may allow a greater scope. ${ }^{40}$ The initiative and referendum are also granted to the residents of certain special districts by Elections Code sections 5150-5203.

At each level of government-state, county, city and special district - the scope of the initiative and referendum will be no broader than the power of the legislative body at that level. ${ }^{41}$ Bearing in unind that there are some differences due to the varying characters of these governmental entities, and that a charter provision may allow a broader apphication of these powers, it is nevertheless meaningful to discuss the scope of the initiative and referendum as largely the same at all levels. ${ }^{42}$ The re-

\footnotetext{
36 See text accompanying notes 153-61 infra.

37 CaI. Const. art. IV, $\S 1$ (II 5,6$)$. See text accompanying notes 99-152 infra.

38 CAI. Const. art. IV, $\S 1$ (П 6).

39 Car. Const. art. IV, \& 1 (II 19).
}

40 For the distinction between charter and general law cities, see note 16 supra. The possible broader scope of these powers in charter cities results from the interpretation given the language of article IV, section 1: "Nothing contained in this section shall be construed as affecting or limiting the present or future powers of cities or cities and counties having charters...." This sentence is read to mean that a charter may add to the power reserved by the constitution but may not reduce it. See Hunt v. City of Riverside, 31 Cal. 2d 619, 62223, 191 P.2d 426, 428 (1948); Hopping v. City of Richmond, 170 Cal. 605, 610-11, 150 Pac. 977, 979 (1915); Brown v. Boyd, 33 Cal. App. 2d 416, 421, 91 P.2d 926, 929-30 (1939). But see Lawing v. Faull, 227 Cal. App. 2d 23, 38 Cal. Rptr. 417 (1964) (signature requirement on petitions may be raised). As evidenced by the results in the foregoing cases which enunciate the rule, the courts do not readily construe charters to allow broader reserved powers. See also Housing Authority v. Superior Court, 35 Cal. 2d 550, 558, 219 P.2d 457, 461 (1950). But see Atlas Hotels, Inc. v. Acker, 230 Cal. App. 2d 658, 661, 41 Cal. Rptr. 231, 233 (1964).

41 See Hurst v. City of Burlingame, 207 Cal. 134, 140, 277 Pac. 308, 311 (1929). For example, the initiative in a city will be limited to matters of municipal concern, as is the power of the city council. See Mervynne v. Acker, 189 Cal. App. 2d 558, 561, 563, 11 Cal. Rptr. 340, 342, 344 (1961); People v. Willert, 37 Cal. App. 2d Supp. 729, 93 P.2d 872 (1939). An analogous restriction would exist on the statewide initiative as to legislative matters that are the exclusive domain of the federal government. See, e.g., McDernott $\mathrm{v}$. Wisconsin, 228 U.S. 115 (1913).

42 The initiative and referendum were discussed in these terms in Dye v. City of Compton, 80 Cal. App. 2d 486, 489, 182 P.2d 623, 625 (1947) (mumicipal referendum power same as statewide) (dictum). 
mainder of this discussion, then, will encompass all levels of government in the state, and will consider the various restrictions on the initiative and referendum and the extent to which, as applied by the courts, they impinge upon the scope of these reserved powers.

\section{III}

\section{RESTRICTIONS ON THE INITIATIVE AND REFERENDUM}

In dealing with the initiative and referendum the courts oscillate between two opposing principles. The first is that the initiative and referendum provisions of the constitution shall be broadly construed so as to inaintain the maximum power in the people. ${ }^{43}$ The second, the counterprinciple, was first raised in an early street improvement case ${ }^{44}$ in circumstances in which its application might have been questioned; ${ }^{45}$ but it has been applied in more recent cases firmly establishing its stature. ${ }^{40}$ By this counter-principle, "if essential governmental functions would be seriously impaired by the [initiative or] referendum process, the courts, in construing the applicable constitutional and statutory provisions, will assume that no such result was intended [by the drafters]."177 The results reached in the initiative and referendum cases represent largely a balance struck between these two competing principles; ${ }^{48}$ in certain instances it might be argued that a shift in the balance could be achieved if desired.

\section{A. Ultra Vires or Unconstitutional Acts}

It should surprise no one to find that the initiative ${ }^{40}$ may not be used to enact a measure which would contravene a paramount law. Whether the paramount law is a constitution, a city charter, or, as in the case of local units, a state statute, since the local legislative body must conform to the law, so must the initiative and referendum within that unit. ${ }^{50}$

43 See, e.g., Hunt v. City of Riverside, 31 Cal. 2d 619, 628, 191 P.2d 426, 431 (1948); Ley v. Dominguez, 212 Cal. 587, 593, 299 Pac. 713, 715 (1931); Martin v. Smith, 176 Cal. App. 2d 115, 1 Cal. Rptr. 307 (1959); McClure v. Nye, 22 Cal. App. 248, 251, 133 Pac. 1145, 1147 (1913).

44 Chase v. Kalber, 28 Cal. App. 561, 569-70, 153 Pac. 397, 400 (1915).

45 The court could have decided the case by treating the matter as one of strictly nongeneral interest. See text accompanying notes 183-88 infra.

46 See Geiger v. Board of Supervisors, 48 Cal. 2d 832, 839, 313 P.2d 545, 549 (1957) (referendum) (dictum); Simpson v. Hite, 36 Cal. 2d 125, 134-35, 222 P.2d 225, 230-31 (1950) (initiative) (semble); Hunt v. City of Riverside, 31 Cal. 2d 619, 628-29, 191 P.2d 426, 431-32 (1948); Alexander v. Mitchell, 119 Cal. App. 2d 816, 828, 260 P.2d 261, 268 (1953) (initiative) (dictum).

47 Geiger v. Board of Supervisors, supra note 46.

48 Cf. Note, 3 Stan. L. Rev. 497,509 (1951).

49 The discussion which follows primarily relates to the initiative, although it is possible that the referral of a patently unconstitutional or ultra vires measure might be enjoined to spare the expense of a needless election or campaign.

50 See Hurst v. City of Burlingame, 207 Cal. 134, 140-41, 277 Pac. 308, 311 (1929) 
The term "ultra vires" will be used generally here to denote those situations in which an act is beyond the power of a legislative body because not authorized by its organic law or in conflict with some paramount law.

\section{Prior-to-Enactment Determination of Validity}

The most obvious type of ultra vires act would be an attempt to initiate at the municipal level a measure of exclusively state concern-the authority of cities being restricted to municipal concerns. ${ }^{51}$ Likewise a statewide initiative might conceivably tread on ground occupied exclusively by federal legislation. ${ }^{52}$ And any measure conflicting with the federal or state constitutions would, under familiar principles of constitutional law, be of no effect. ${ }^{53}$ The interesting point is, however, that the

(Zoning Act of 1917). The characteristic which distinguishes "ultra vires acts," as discussed here, from other restrictions on the initiative and referendun, as discussed elsewhere in this Comment, is this derivative element. The restrictions on the initiative and referendun presently being considered exist because the legislative body within the given unit is subject to a paramount law, whereas other restrictions on the initiative and referendum apply to the initiative and referendum per se.

51 See note 41 supra. In numerous cases, the ultra vires doctrine has been utilized by the courts in a far more sophisticated manner than in the simple case where a matter is clearly not a municipal affair and hence not subject to the local initiative. One such case, Mitchell v. Walker, 140 Cal. App. 2d 239, 295 P.2d 90 (1956), involved an initiative to set pohice and firemen wages in the city at a constant percentage above that paid to county police and firemen, presumably to help in recruiting top men. The court held that state law nuade it the duty of the city council to fix the salaries of the city's officers and employees. The proposed initiative would in effect delegate the power to set these particular wages to the county board of supervisors. Hence the measure was ultra vires. See also Alexander v. Mitchell, 119 Cal. App. 2d 816, 821-22, 260 P.2d 261, 263-64 (1953) (alternative holding) (city cannot divest itself of state-granted power of eminent domain).

52 See note 41 supra.

53 Mulkey v. Reitman, 64 A.C. 557, 413 P.2d 825, 50 Cal. Rptr. 881 (1966); Weaver v. Jordan, 64 A.C. 243,411 P.2d 289, 49 Cal. Rptr. 537 (1966).

These decisions have, in some quarters, evoked vituperative criticism and charges of subverting the public will. See, e.g., Los Angeles Times, May 11, 1966, pt. I, p. 20, col. 4; id., May 12, 1966, pt. I, p. 1, col. 1. While the measure invalidated in each case had been passed by a 2 to 1 public vote (see Jordan, Caitfornia Statrament of the Vote, November 3,1964 , at 25), no quarrel can be made with the subordination of these state measures to the federal constitution. The suprenacy of the federal constitution has been too long established for any doubts to remain. Disagreements, if any, must be voiced with the interpretation of the federal constitution, not with its application.

To avoid future misunderstanding by voters who may be unaware of the subtleties of constitutional law doctrines, a procedure might be instituted whereby the Attorney-General could append a cautionary statement to the ballot summary, in appropriate instances, advising that it is his opinion that the measure conflicts with the constitution and could probably be invalidated even if enacted. The proponents might be permitted a sentence stating their view or hope that the measure would be upheld. Additionally, when it is sought to keep a nieasure off of the ballot, the courts might determine its validity prior to enactment. 
courts frequently ${ }^{54}$ decide these questions of ultra vires or unconstitutionality before a measure is enacted when it is souglit to enjoin the submission of a measure to the people, ${ }^{55}$ or when a public official refuses to perform his ministerial duty of presenting the measure to the voters and mandate is sought to compel its submission. ${ }^{56}$

The courts have not thoroughly discussed the law governing these prior-to-enactment determinations of validity. The practice apparently derives from the discretionary power of a court of equity to prevent a public waste. This is reflected in the rule, not always cited but seemingly descriptive of what the courts do in these cases, which was stated and apphed in Harnett $v$. County of Sacramento ${ }^{57}$ when the court enjoined an initiative measure to reapportion county supervisorial districts:

Where it is proposed to hold an election for the submission of a measure to the popular vote, and that measure will be wholly void and inoperative even if adopted by the people, the courts may, at the instance of a resident taxpayer, enjoin the holding of the election upon the ground that it will be a useless expenditure and waste of public funds (Code Civ. Proc., sec. 526a). ${ }^{58}$

While it is unclear whether a special election was mvolved in Harnett, in which case the waste to be prevented would presumably be greater than if only an additional proposition for a general ballot were at issue, the courts have in subsequent cases freely interfered with the submission of measures without specifying whether a special election was involved. ${ }^{59}$ The argument that the courts may not restrain action of a legislative body, and hence may not restrain an initiative measure, was rejected by the Harnett court. ${ }^{60}$ This rejection appears supportable since

54 But see Lewis v. Jordan, Sac. No. 7549, Cal. Sup. Ct., June 3, 1964 (memorandum decision); Wind v. Hite, 58 Cal. 2d 415, 374 P.2d 643, 24 Cal. Rptr. 683 (1962); Jensen v. Hite, L.A. No. 26956, Cal. Sup. Ct., August 10, 1962 (memorandum decision); Green v. Jordan, 216 Cal. 318, 14 P.2d 297 (1932), discussed in text accompanying notes 67-73 infra. The brief Lewis v. Jordan opinion is reproduced in Clancy \& Nemerovski, Some Legal Aspects of Proposition Fourteen, 16 Hastings L.J. 3 (1964).

This policy of decision prior to enactment carries through to the application of other restrictions as well. See, e.g., Alexander v. Mitchell, 119 Cal. App. 2d 816, 260 P.2d 261 (1953).

${ }^{55}$ See, e.g., Simpson v. Hite, 36 Cal. 2d 125, 222 P.2d 225 (1950); McFadden v. Jordan, 32 Cal. 2d 330, 196 P.2d 787 (1948), cert. denied, 336 U.S. 918 (1949) (enjoiming submission of proposed state constitutional amendment); Harnett v. County of Sacramento, 195 Cal. 676, 235 Pac. 445 (1925); Mueller v. Brown, 221 Cal. App. 2d 319, 34 Cal. Rptr. 474 (1963).

56 See, e.g., Blotter v. Farrell, 42 Cal. 2d 804, 270 P.2d 481 (1954); Housing Authority v. Superior Court, 35 Cal. 2d 550, 219 P.2d 457 (1950); Mervynne v. Acker, 189 Cal. App. 2d 558, 11 Cal. Rptr. 340 (1961); Mitchell v. Walker, 140 Cal. App. 2d 239, 295 P.2d 90 (1956).

57195 Cal. 676, 235 Pac. 445 (1925).

68 Id. at 683,235 Pac. at 448.

59 See cases cited notes 55 and 56 supra.

60 Harnett v. County of Sacramento, 195 Cal. 676, 682-83, 235 Pac. 445, 448 (1925). 
the purpose of the injunction is to prevent the waste of public funds and since no comparable substantial waste is likely to result from the passage of an invalid law by an ongoing legislative body. It might be contended that this prior determination of validity amounts to an umecessary restriction on the initiative, since a court may unconsciously slow less respect for a measure which is merely a proposal than for one which is a duly enacted law. A sufficient answer seems to be that if the measure is invalid it would be of no effect if passed, that making the determination before its enactment merely moves forward the time of the declaration, and that the benefit to be derived outweighs any dangers which may be envisioned. ${ }^{11}$ This answer could be justified only if the courts gave to the proposed initiative measure the same presumption in favor of validity and the same severability privileges as would be accorded a measure already enacted. ${ }^{62}$ In fact, they have done exactly this ${ }^{63}$ and examples to the contrary are rare. One such rare case, Mueller v. Brozen, ${ }^{64}$ treated an initiative measure to preserve a courthouse park area and to provide for its permanent maintenance as an illegal attempt to bind future boards of supervisors. The language of the measure did not compel such a construction, for the measure would have been subject to repeal by a later initiative $^{65}$ or by later supervisor action approved by the electorate. ${ }^{66}$ The reasoning of the case belied the apparent underlying concern with preventing the loss of federal funds which might result from the delay a public vote would cause.

While the courts lave ruled on validity prior to enactment numerous times ${ }^{67}$ they have also refused to do so on several occasions. ${ }^{68}$ Whether the restraint in these latter cases evidences anything more than the discretion traditionally exercised by a court of equity is unclear. In two of the cases, the time available was inadequate to allow proper consideration of the questions presented; ${ }^{69}$ but in the two other cases the court had

\footnotetext{
61 Id. at 683, 235 Pac. at 448.

62 A discussion of the problems involved here appears in Note, 14 CALIF. L. REv. 37 (1925).

o3 See Blotter v. Farrell, 42 Cal. 2d 804, 270 P.2d 481 (1954); Hughes v. City of Lincoln, 232 Cal, App. 2d 741, 43 Cal. Rptr. 306 (1965); Fletcher v. Porter, 203 Cal. App. 2d 313, 324, 21 Cal. Rptr. 452, 458 (1962); Alexander v. Mitchell, 119 Cal. App. 2d 816, 829-30, 260 P.2d 261, 268-69 (1953) (severability).

64 221 Cal. App. 2d 319, 34 Cal. Rptr. 474 (1963). See also Mitchell v. Walker, 140 Cal. App. 2d 239, 295 P.2d 90 (1956).

${ }^{65}$ Cf. Blotter v. Farrell, 42 Cal. 2d 804, 811, 270 P.2d 481, 485 (1954).

68 See Cax. Const. art. IV, \& lb which, under Geiger v. Board of Supervisors, $48 \mathrm{Cal}$. 2d 832, 836, 313 P.2d 545, 546 (1957), and Dye v. City of Compton, 80 Cal. App. 2d 486, 489 , 182 P.2d 623, 625 (1947), would apply at the local level.

67 See cases cited notes 55 and 56 supra.

68 See cases cited note 54 supra.

69 Jensen v. Hite, L.A. No. 26956, Cal. Sup. Ct., August 10, 1962 (memorandum decision); Green v. Jordan, 216 Cal. 318, 14 P.2d 297 (1932).
} 
sufficient time and yet preferred to defer deciding the constitutional question until the voters could express themselves. ${ }^{70}$ Does this mean that when an injunction is sought on constitutional grounds it is less likely to be granted, or will not be granted at all? It would appear that if either of these possible inferences has validity, it is the former. While no California initiative has been enjoined as violative of the federal constitution, one has been enjoined in McFadden v. Jordan ${ }^{71}$ as conflicting with the state constitution. McFadden might be distinguished by separating "procedural" conflicts from "substantive" conflicts and conceding that an injunction may issue as to a "procedural" defect. ${ }^{72}$ But such an analysis is unsatisfying. Why should a "procedural" defect cry for decision prior to enactment of the measure when a "substantive" one does not? The issue could be determined after a vote as easily in either case, and the same sort of egregious waste could be prevented by a prior decision. Hence $M c F$ adden and reason would seem to allow enjoining a measure on constitutional grounds in at least some cases. ${ }^{73}$

Is the discretion exercised by the court different when a measure is challenged on constitutional grounds from when a challenge is based upon an alleged conflict with some other paramount law? Perhaps the strong policy of avoiding decision on constitutional questions carries over into this area to make the courts more reluctant to enjoin an initiative on a constitutional ground. Deferring judgment and allowing the measure to go to a vote, which, if adverse, will avoid the necessity of a decision entirely, finds strong support in this general policy. However, if the courts are "more reluctant," it sliould be a matter of imperceptible degree because a similar policy, that of judicial parsimony, also militates against deciding questions which might otherwise be avoided.

One may wonder whether a court has discretion to defer passing on validity regardless of the manner in which the question comes before it. The cases in which the courts have refrained from deciding validity prior to enactment have all been prohibition cases where the suits were to enjom submission of an alleged invalid measure. Where a public official has balked in his ministerial duty on the ground of the measure's invalidity and mandamus lias been sought to compel him to submit the measure, the courts have apparently always ruled on the measure's validity. ${ }^{74}$ They have not addressed themselves to this issue, but have

70 Lewis v. Jordan, Sac. No. 7549, Cal. Sup. Ct., June 3, 1964 (memorandum decision); Wind v. Hite, 58 Cal. 2d 415, 374 P.2d 643, 24 Cal. Rptr. 683 (1962).

7132 Cal. 2d 330, 196 P.2d 787 (1948) (omnibus "constitutional amendment" held revision of constitution requiring constitutional convention).

72 See Annot., 19 A.L.R.2d 519, 521 (1951).

73 See also State ex rel. Steen v. Murray, 144 Mont. 61, 394 P.2d 761 (1964). Cf. Livermore v. Waite, 102 Cal. 113, 36 Pac. 424 (1894).

74 See cases cited note 56 supra. 
perhaps assumed that the nature of mandamus requires a decision on the merits of the measure. California Code of Civil Procedure section 1085 states that mandamus will issue to compel performance of an act "specifically enjoined" as a duty on a public official. However, mandamus will not issue to compel performance of an act that will be void or of no effect. ${ }^{75}$ Perhaps in determining whether a duty exists or whether the public official's act will be futile the court must necessarily decide the validity of the measure. If this is true, then the mamer in which a given question reaclies the court may determine the outcome. The court would have to rule on the measure's validity in the mandate situation but would have discretion to defer judgment when a prohibitory injunction was souglit. However, this result might be avoided. At least when the measure is not patently void on its face, when reasonable men might differ, a court could construe the public official's duty as compelling him to process any initiative which is not clearly void. The court could order the measure submitted to the public subject, as in the prohibition cases, to a challenge of validity that could be lodged if the measure should pass. ${ }^{76}$ The official's act would not be futile for he would be submitting a measure for a public vote and that vote would take place. By this approach, a court could exercise the same discretion and weigh the same considerations as in the prohibition cases.

What these considerations are is another question. The courts have not discussed this point, but the unarticulated practice may be said to involve a balancing test-weighing the value of preventing waste on the one hand against the value of allowing the public vote on the other. ${ }^{77}$ If a measure is patently void or unconstitutional on its face, then the waste should be prevented. This is fairly clear. Beyond, however, lie the harder cases. If a close question is presented, a number of factors might come into play. The court could decide whether the issue raised is one of legal technicalities or one involving some public policy considerations. If the former, the court might choose to pass on the law prior to enactinent, especially if the legal question is one that needs clarification. If the legal question is one rampant with implications the court would prefer to avoid, judgment might be withheld on the chance that the measure may fail in the vote. If public policy questions are presented, the court might defer judgment, pending the public's expression on the matter. ${ }^{78}$ Certainly though, this is an area where prediction will be difficult.

\footnotetext{
75 Myers v. Stringham, 195 Cal. 672, 676, 235 Pac. 448, 449 (1925). Cf. Pacific Employers Ins. Co. v. Carpenter, 10 Cal. App. 2d 592, 52 P.2d 992 (1935).

${ }^{76}$ See Myers v. City of Pismo Beach, 241 A.C.A. 316, 325, 50 Cal. Rptr. 402, 407-08 (1966).

77 See Harnett v. County of Sacramento, 195 Cal. 676, 682-83, 235 Pac. 445, 448 (1925). 78 See Note, 14 CaLrF. L. Rev. 37, 43 (1925).
} 


\section{Exclusive Delegations and Special Procedures}

In addition to the consideration of validity prior to enactment, there are two other elements worthy of note in this context of ultra vires or unconstitutional acts. First, in numerous instances a statute or charter may state that a given responsibility "shall" be exercised by the local "legislative body"- the "city council," for example. More often than not such a provision will probably have been drafted with no thought of the initiative and referendum-only with the purpose of spelling out a local power. Nonetheless, in a few cases the courts have construed such provisions as giving the particular power to the local legislative body to the exclusion of the initiative and referendum. ${ }^{79}$ The representatives of the people may make the decision but the people themselves may not. This anomaly may be reasonable in cases where the referendum machinery poses a special problem, ${ }^{80}$ or where an act must be performed and the referendum presents a threat of continual public rejection of proposals so that needed action may be effectively prevented. ${ }^{81}$ But where there is no special reason for holding that a power is granted exclusively to the local legislative body, a court should not read the statute to find

79 Geiger v. Board of Supervisors, 48 Cal. 2d 832, 838, 313 P.2d 545, 548 (1957) ("board of supervisors"); Simpson v. Hite, 36 Cal. 2d 125, 129-30, 222 P.2d 225, 228 (1950) ("board of supervisors shall"); Myers v. City of Pismo Beach, 241 A.C.A. 316, 320, 50 Cal. Rptr. 402, 404 (1966) ("legislative body"); Mervynne v. Acker, 189 Cal. App. 2d 558, 11 Cal. Rptr. 340 (1961) ("legislative body"); Mitchell v. Walker, 140 Cal. App. 2d 239, 295 P.2d 90 (1956) (by implication) ("shall").

${ }^{80}$ See Mervynne v. Acker, supra note 79 at 565, 11 Cal. Rptr. at 345, suggesting that the threat of "cumbersome delay and heavy expense" posed by the initiative and referendum is a factor to be considered in determining whether they apply. In response, it might be said that these devices will almost invariably entail "cumbersome delay and heavy expense."

81 See Simpson v. Hite, 36 Cal. 2d 125, 133, 222 P.2d 225, 230 (1950). In Simpson, since the county board of supervisors was required by state law to provide adequate court facilities, the court argued the referendum could not apply because the public might veto all board proposals and prevent it from acting. If any board failed to provide facilities, the courts could direct the sheriff of the county to provide the facilities at the county's expense. CAL. Gov's Code \& 68073 (formerly CAx. Code of Crv. Proc. \& 144). It seems that this same section would apply if the public votes should impede provision of the facilities. The state had no guarantee the board would act in situations where the referendum did not apply, and the remedy would be just as effective if it did apply.

Along the same lines, in Housing Authority v. Superior Court, 35 Cal. 2d 550, 219 P.2d 457 (1950), where the authority to declare a need for public housing was held to be vested exclusively in the city council, there was no compulsion on the city council to make a finding and hence it imight be said that no harm could result from the local citizenry's use of the initiative to make the finding or of the referendum to veto it. Both Simpson and this case perhaps make better sense when it is realized that they involved matters of state concern. Perhaps the state concern in the matter provides a legitimate state interest in having these matters free from the local initiative and referendum. See the rationale stated in Geiger v. Board. of Supervisors, 48 Cal. 2d 832, 837-38, 313 P.2d 545, 547-48 (1957). Nonetheless, the arguments used in these cases should carry less weight when the matter delegated is not a state concern. 
such a restriction. The mere use of the word "shall," usually used to describe something mandatory, ${ }^{82}$ should not be enough to compel the conclusion that the initiative and referendum were to be excluded..$^{83}$ The statute may well have been drafted with the word "shall" long before the institution of the initiative and referendum in this state. ${ }^{84}$ And the same may be true of other terms-such as "board of supervisors" - which may or may not have been used to exclude the initiative and referendum. ${ }^{85}$

If the court concludes that the legislature did in fact intend that the initiative and referendum should be unavailable for the particular matter, then the issue presented is the same as that raised by the second matter to be discussed here-the application of the ultra vires doctrine when state law, ${ }^{86}$ the constitution, ${ }^{87}$ or a local charter ${ }^{88}$ has spelled out certain procedures to be followed in adopting certain types of legislation. The common issue is whether the legislature in fact has the power to narrow the scope of the initiative and referendum; this will be discussed after some introductory remarks concerning these special procedures.

Many types of legislation have special procedures prescribed for their enactment. Typical of these procedures are special vote requireinents, ${ }^{89}$ hearings or special notices, ${ }^{90}$ statutory methods of selecting

82 See, e.g., Cax. Educ. Code § 36; CaL. Elect. Code § 15; Cat. Gov'x Code § 14.

83 In Mitchell v. Walker, 140 Cal. App. 2d 239, 295 P.2d 90 (1956), the court implied that the word "shall," as used in California Government Code $\$ 36506$, might be held to vest exclusive legislative authority in the city council (making the matter "administrative") in the manner in which such exclusive authority was found in the cases discussed in note 81 supra. However, unlike those cases, a matter of state concern was not involved. If a finding of exclusive authority had been made, it would have rested solely on the use of the word "shall," a word that was in the statute when it was originally enacted in 1883 (Cal. Stats. 1883, ch. 49, at 267), some thirty years before the institution of the initiative and referendum in California. See note 2 and accompanying text supra. See also Myers v. City of Pismo Beach, 241 A.C.A. 316, 320, 50 Cal. Rptr. 402, 404 (1966).

84 See note 83 supra.

85 See Geiger v. Board of Supervisors, 48 Cal. 2d 832, 838, 313 P.2d 545, 548 (1957); Myers v. City of Pismo Beach, 241 A.C.A. 316, 320, 50 Cal. Rptr. 402, 404 (1966) ("legislative body").

86 See Simpson v. Hite, 36 Cal. 2d 125, 134-35, 222 P.2d 225, 230-31 (1950); Hurst v. City of Burlingame, 207 Cal. 134, 277 Pac. 308 (1929); Galvin v. Board of Supervisors, 195 Cal. 686, 235 Pac. 450 (1925); Harnett v. County of Sacramento, 195 Cal. 676, 235 Pac. 445 (1925).

87 See McFadden v. Jordan, 32 Cal. 2d 330, 332, 196 P.2d 787, 789 (1948), cert. denied 336 U.S. 918 (1949); Alexander v. Mitchell, 119 Cal. App. 2d 816, 822, 260 P.2d 261, 264 (1953) (alternative holding).

88 See Myers v. Stringham, 195 Cal. 672, 235 Pac. 448 (1925).

88 Harnett v. County of Sacramento, 195 Cal. 676, 235 Pac. 445 (1925) (two-thirds vote of supervisors necessary to redistrict).

90 Hurst v. City of Burlingame, 207 Cal. 134, 277 Pac. 308 (1929) (zoning legislation). 
contract recipients, ${ }^{21}$ and prior approval of plans by administrative agencies..$^{22}$ Because the initiators could not adhere to these procedures, or because adoption of an initiative measure would be inconsistent with these procedures, as by eliminating any administrative discretion the procedures were intended to confer ${ }^{93}$ the initiative has been held unavailable where such special procedures were applicable. ${ }^{94}$ The referendum, however, would apply because its timing, coming after passage of the measure, would not conflict with the special procedures. ${ }^{95}$

The upshot of the applicability of special procedures nuaking the initiative unavailable, and of the possibility of legislation conferring a power on the local legislative body to the exclusion of the initiative and referendum, is that the state legislature lias the power to circumscribe substantially the scope of the imitiative and referendun despite the seeningly contrary statenent in article IV, section 1 of the constitution that legislation may be enacted to facihtate the operation of the section "but in no way linniting or restricting either the provisions of this section or the powers herein reserved."${ }^{\prime 96}$ This apparent anomaly disappears when it is reahzed that varying provisions of the constitution must be harmonized with one another. Of necessity, to exercise its other constitutionally granted powers effectively, the legislature must and does have the power to limit indirectly the initiative and referendum when pursuing other legitimate goals. ${ }^{97}$ Any other construction of the language would make the initiative and referendum inviolable at the expense of a vast curtailment of state legislative powers. Hence the legislature may act to preempt a field by nuaking it a nuatter of state concern, ${ }^{98}$ thereby placing it chise).

01 Galvin v. Board of Supervisors, 195 Cal. 686, 235 Pac. 450 (1925) (toll bridge fran-

92 Simpson v. Hite, 36 Cal. 2d 125, 134-35, 222 P.2d 225, 230-31 (1950) (alternative holding) (county courthouse sites subject to approval of planning commission).

93 See Simpson v. Hite, supra note 92; Hughes v. City of Lincoln, 232 Cal. App. 2d 741, 748-49, 43 Cal. Rptr. 306, 311-12 (1965) (no administrative discretion).

94 See cases cited notes 87-92 supra.

${ }^{95}$ See Johnston v. City of Claremont, 49 Cal. 2d 826, 323 P.2d 71 (1958); Hurst v. City of Burlingaine, 207 Cal. 134, 141-42, 277 Pac. 308, 311-12 (1929) (dictum). But see Chase v. Kalber, 28 Cal. App. 561, 573-74, 153 Pac. 397, 402 (1915) (dictum).

${ }^{98}$ CAL. Const. art. IV, $\S 1$ (II 19). The revision of article IV, $\S 1$, due to be voted on in November, deletes this clause as surplusage. Constrrution Revision Comarssion at 49-50. Even without this specific provision against legislative abridgement of the initiative and referendum, it would seem that the legislature could pass no law restricting the scope of these reserved powers. See Hill v. Board of Supervisors, 176 Cal. 84, 86, 167 Pac. 514, 515 (1917) overruled on other grounds in Simpson v. Hite, 36 Cal. 2d 125, 131-32, 222 P.2d 225, 229 (1950). See also Geiger v. Board of Supervisors, 48 Cal. 2d 832, 837, 313 P.2d 545, 547 (1957).

97 See Harnett v. County of Sacramento, 195 Cal. 676, 235 Pac. 445 (1925).

98 See Note, 53 CaLF. L. REV. 902, 909 (1965). 
beyond the scope of the local initiative and referendum. ${ }^{92}$ And likewise the legislature can impose special procedures for the enactment of certain types of legislation and can, if there are good reasons, restrict a given subject to the local legislative body. But there is reason for closer judicial scrutiny of the indirect restrictions in these latter cases. When a field is made one of state concern, both the local legislative body and the initiative and referendum are excluded. But when a special procedure is imposed, and by definition when a matter is restricted exclusively to the local legislative body, the local legislative body can still act. Only the initiative and referendum are barred. For this reason, such restrictions present a special danger that the initiative and referendum might be unnecessarily eroded inadvertently, or worse yet, by legislative design. Hence the courts should avoid construing special procedures as applying to the initiative unless there are strong reasons for such application. Likewise, statutes should not be readily interpreted to vest exclusive power in the local legislative body in the absence of compelling reasons.

Two cases are at least encouraging in this regard. In Blotter v. Farrell, ${ }^{100}$ a majority of the supreme court allowed submission of an imitiative measure to redistrict a general law city despite dissents urging that the state law prescribed procedures to be followed in districting which should necessarily apply to redistricting. ${ }^{101}$ The majority refused to iniply the procedural restriction.

In Hughes v. City of Lincoln, ${ }^{102}$ the court construed the state law ${ }^{103}$ requirmg the State Board of Public Health's approval of local water system practices so as to avoid the procedural conflict. A proposed initiative to prohibit fluoridation of the city's water supply was challenged by city officials who claimed that since all details relating to the city's water plan were subject to the Board's approval, no measure could be initiated on the subject. The court held that the law required the Board to approve the plan so long as the water would be pure and potable. Since fluoridation had no relation to purity, the Board would have to accept the city's decision if the imitiative measure were enacted.

If a finding that the procedure applies to the imitiative or that the legislature intended to restrict the subject to the local legislative body is unavoidable, then the court slould have the further duty to weigh the value of the procedure or restriction against the value of the imitia-

99 See note 41 supra.

10042 Cal. 2d 804, 270 P.2d 481 (1954).

101 See Blotter v. Farrell, 42 Cal. $2 d$ 804, 813-15, 270 P.2d 481, 486-87 (1954) (dissenting opinions).

102232 Cal. App. 2d 741, 43 Cal. Rptr. 306 (1965).

103 Car. Heattr \& Saf. Code § 4021. 
tive and referendum. If there are valid reasons for the restriction, reading various provisions of the constitution to maintain harmony will require recognizing the restriction as indirect. Conversely, the lesser the value of the restriction, the greater will be its resemblance to a direct and needless restriction on the reserved powers; and, in some circumstances, a court may and slould strike it down as unconstitutional. ${ }^{104}$

\section{B. Administrative-Legislative Distinction}

A major restriction on both the initiative and the referendum stems from the distinction the courts draw between administrative and legislative acts-the initiative and referendum being applicable only to the latter. This distinction is most commonly invoked when referral is souglit for a measure passed by a local legislative body whicl exercises administrative as well as legislative powers. It derives from several sources: from the placement of the initiative and referendum provisions in the article conferring the state legislative powers, ${ }^{105}$ from the doctrine of separation of powers, ${ }^{106}$ from the specific language of article IV, section $1,{ }^{107}$ and from an arguable intent of the drafters that the initiative and referendum were to apply only to broad policy decisions but not to administrative acts, because applying it to the latter would too seriously hamper the conduct of government. ${ }^{108}$ To draw a distinction is sound, especially where the local governing body exercises dual powers, because at some point administrative discretion must be left unfettered to carry out the policies of the government. But it is also important that matters of legitimate public concern not be too facilely included among those designated "administrative."

\section{1. "Historical" Test}

Attempts have been made to state a rule for differentiating administrative from legislative acts. Most often quoted is the statement in McKevitt v. City of Sacramento: $:^{100}$

104 CAI. Const. art. IV, $\S 1$ (I 19). See note 96 supra and accompanying text.

105 Cax. Const. art. IV, \& I (II 1): "The legislative power of this state shall be vested . . . See Hopping v. City of Richmond, 170 Cal. 605, 609-10, 150 Pac. 977, 978 (1915).

108 The argunent would be that just as under the separation of powers theory the executive branch of government should be independent of the legislative branch, so it should be likewise independent of the initiative and referendum. See Hopping v. City of Richmond, supra note 105.

107 (II 1): "[T] refer] any act, or section or part of any act, passed by the Legislature." (Emphasis added.) 108 See Chase v. Kalber, 28 Cal. App. 561, 569-70, 153 Pac. 39\%, 399-400 (1915); cases cited note 46 supra.

10955 Cal. App. 117, 124, 203 Pac. 132, 136 (1921). 
Acts constituting a declaration of public purpose, and making provision for ways and means of its accomplishment, may be generally classified as calling for the exercise of legislative power. Acts which are to be deemed as acts of administration, and classed among those governmental powers properly assigned to the executive department, are those which are necessary to be done to carry out legislative policies and purposes already declared by the legislative body, or such as are devolved upon it by the organic law of its existence.

While such statements provide some indication of how the distinction is drawn, they have limited utility. Basically, the distinction is drawn on a case-by-case basis by reference to history and the traditional classification of the matter under consideration. ${ }^{110}$ This, however, presents a problem for those who must decide whether a given measure is administrative or legislative.

The notion of acts pursuant to prior established policy, imphicit in the last part of the $M c K$ evitt rule, may be helpful within limits. Normally administrative acts are those done in pursuance of some established legislative policy. For example, a city council might vote to embark on a project. A subsequent resolution appropriating funds to finance the project would seem to be "administrative" and not subject to referral."11 However, that the new resolution is pursuant to a prior established policy should not resolve the matter. If, for example, the second resolution declares some additional policy, perhaps by appropriating more funds than were reasonably anticipated when the first measure was passed, then a new legislative element may be said to be present and the matter should be subject to referral. ${ }^{112} \mathrm{~A}$ clearer example would be where a resolution is passed stating that a new city hall sliall be built. After study, a new resolution is passed designating the site. This latter resolution should be subject to the referendum. ${ }^{113}$

The courts' ultimate test then is whether the matter is administrative or legislative historically, traditionally and in case law. Furthermore, the controversial nature of the matter ought to be considered. ${ }^{114}$ If the matter is hikely to arouse the attention and favor or opposition of the voters, then it should not be kept off the ballot by being termed "administrative." The initiative and referendum were created to allow public votes on public issues; the more controversial an issue, the more important it is that the voters should be able to express themselves on it. This does not mean that a controversy exists, and that the action is no longer adminis-

110 Hopping v. City of Richmond, 170 Cal. 605, 150 Pac. 977 (1915).

111 See id. at 615-16, 150 Pac. at 981.

112 See id. at 611,150 Pac. at 979.

113 Ibid. See Simpson v. Hite, 36 Cal. 2d 125, 131, 222 P.2d 225, 229 (1950).

114 See Hopping v. City of Richmond, 170 Cal. 605, 617, 150 Pac. 977, 981 (1915). 
trative, whenever a group of electors circulates a petition attacking a local action; but it does indicate that people are sufficiently concerned to take action. Hence a court should be slow to classify the matter as "admimistrative." There may be other defects ${ }^{115}$ in the proposal which, despite the ardor of its proponents, make it non-initiable or non-referrable; but if the matter is controversial, a court should rarely label it "administrative."

\section{Effect on Initiative}

The effect of the administrative-legislative distinction on the initiative differs conceptually from its effect on the referendum. If a matter is administrative, the referendum is unavailable to attack it and the initia'tive is unavailable to carry out the legislative policy-for example, to appropriate the money to finance the project previously authorized by resolution. But the initiative could be used to reverse or alter the original policy-presumably even after it has been largely carried out-because the local legislative body, acting legislatively, can do so. ${ }^{110}$

This analysis presents a problem when, for example, a county board of supervisors makes plans to build a courthouse, passes a resolution to that effect, purchases property, enters into contracts, and then finds the project challenged by an initiative to rescind the previous acts and proposing a different site for the courthouse. When this situation arose in Simpson $v$. Hite ${ }^{117}$ the court was able to avoid the issue by holding that provision of county courthouses was a matter of state concern and that in providing a courthouse the board of supervisors was acting in an administrative capacity as an agent of the state. Hence the initiative could not be used. Had the matter been one of exclusively local concern, like the construction of a city hall, ${ }^{118}$ the court would have been confronted with a difficult decision. In such a case a notion of laches might be used to prevent a belated use of the initiative to attack a measure which could have been timely attacked by a referendum before the part performance. However, if the public would approve the initiative, with the knowledge that public funds would thereby be wasted by abandonment of a partially completed project, then perhaps it is not a court's place to prevent it froin doing so.

115 For example, it may be a matter of non-general concern. See text accompanying notes 182-84 infra.

116 See Blotter v. Farrell, 42 Cal. 2d 804, 811, 270 P.2d 481, 485 (1954) (power to legislate includes power to repeal). But see Alexander v. Mitchell, 119 Cal. App. 2d 816, 827, 260 P.2d 261, 267 (1953) (dictum).

11736 Cal. 2d 125, 222 P.2d 225 (1950).

118 Simpson v. Hite, 36 Cal. 2d 125, 131, 222 P.2d 225, 229 (1950) ; Hopping v. City of Richmond, 170 Cal. 605, 150 Pac. 977 (1915). 


\section{3. "State Concern" Test}

The holding in the Simpson case also illustrates a second method, in addition to the historical test, by which acts are characterized as "administrative" and hence beyond the reach of the initiative and referendum. Several cases have utilized this rationale ${ }^{119}$ which resembles very much the ultra vires notion discussed earher. The major premise in finding the matter "administrative" is that it is a matter of state concern" which by itself would put it beyond the reach of the local initiative and referendum. ${ }^{21}$ The added element is the use of the local legislative body by the state in place of a state administrative agency. In essence, the state has removed the matter from the local sphere and then delegated a part of it back to the local legislative body as the state's administrator. Rather than making this phenomenon a species of "administrative" act, the courts could as well, under the ultra vires concept which is really at the heart of the matter, ${ }^{122}$ treat these cases as involving a duty delegated exclusively to the local legislative body. These would appear to be the strongest cases for finding an exclusive delegation since the state concern in the matter may provide a legitimate state interest in having these matters free fron interference by the local initiative and referendum. In any case, this limitation seems conceptually justified. The only quarrel might be with the characterization of certain matters as "state concerns." For example, in Mervynne v. Acker, ${ }^{123}$ precedent led the court to conclude that parking meters in the City of San Diego were a matter of state concern. The local citizens could not repeal the city ordinances which establisled the ineters.

\section{Applicability at State Level}

While the administrative-legislative distinction is usually discussed in terns of the local level of government, it appears that it would apply equally at the state level. ${ }^{124}$ Acts by the state legislature-for example, a routine appropriation for continuation of a long range project-might be treated as "administrative" under the historical test. Furthermore, especially at the state level, the usual pattern of declaring an act by a

110 Riedman v. Brison, 217 Cal. 383, 387-88, 18 P.2d 947, 948 (1933); Mervynne v. Acker, 189 Cal. App. 2d 558, 11 Cal. Rptr. 340 (1961); Alexander v. Mitchell, 119 Cal. App. 2d 816, 821-22, 260 P.2d 261, 263-64 (1953) (alternative holding).

${ }^{120}$ See Hughes v. City of Lincoln, 232 Cal. App. 2d 741, 747, 749, 43 Cal. Rptr. 306, 310, 311 (1965); Atlas Hotels, Inc. v. Acker, 230 Cal. App. 2d 658, 665, 41 Cal. Rptr. 231, 236 (1964).

121 See note 51 supra and accompanying text.

122 See notes 79-85 supra and accompanying text.

123189 Cal. App. 2d 558, 11 Cal. Rptr. 340 (1961).

124 See Hopping v. City of Richınond, 170 Cal. 605, 609, 150 Pac. 977, 978 (1915). 
legislative body "administrative" might be reversed, and an act of an administrative body might be declared "legislative" and made subject to the initiative and referendum. This has not in fact been done but, arguably, a major policy decision, such as a legislative rule ${ }^{126}$ promulgated by an administrative agency, could be subject to the referendum. The constitution explicitly makes all laws "passed by the legislature"120 subject to referral. Legislative rules have the force of $l a w^{127}$ and may be said to be "passed by the legislature" because they are passed on belialf of the legislature pursuant to delegations of power by the legislature. Had the drafters of the initiative and referendum provisions foreseen the developinent of delegated legislative power they very likely would have intended their provisions to be read in this manner. And as to the constitutionally imposed time linitation for submitting statewide referendum petitions, the language "90 days after the final adjournment of the legislature"128 may be explained by the same failure to anticipate delegated legislative power. For the courts to read in a reasonable time limitation to apply when referral of a legislative rule is the issue would be entirely consistent with, and in furtherance of, the policy of the referenduni that the exercise of legislative power be subject to this direct cleck. Arguably then, the referendum might be available to challenge legislative acts of an administrative body. And even if the referendum is not available, the initiative would probably be available for an indirect attack; just as the legislature could presumably override a legislative rule, so might the people by means of the initiative.

\section{Judicial Review of Urgency Declarations}

Measures enacted for the imniediate preservation of the public peace, liealth or safety are specifically exempted from the referendum, ${ }^{120}$ except those which create or abolish an office, change the salary, term or duties of an officer, grant a franchise or special privilege, or create a vested

1251 Davis, Admonistrative LAw $\$ 5.03$, at 299 (1958). As to California specifically, see id. at \& 5.04 (Supp. 1965, at 123).

120 CaI. Const. art. IV, § 1 (II 1).

127 I Davis, Admonistrative Law 125 (1958).

128 CAL. Const. art. IV, \& 1 (III 5,7 ).

129 Cat. Const. art. IV, § 1 (fII 5, 6); Cal. Elect. Code $\$ 3751$ (counties); Cal. Elect. CODE $\$ 4050$ (cities); CaL. Etect. CODE $\$ 5200$ (special districts).

Whether the initiative could be used to repeal an emergency measure is an open question. For a long time Ohio answered the question in the negative, but then reversed its stand. See State ex rel. Sharpe v. Hitt, 155 Ohio St. 529, 99 N.E.2d 659 (1951), overruling State ex rel. Smith v. City of Fremont, 116 Ohio St. 469,157 N.E. 318 (1927). Since the two devices are basically distinct, and since the emergency measure would be effective until repealed, it would seem that the mitiative ought not to he barred. But cf. Myers v. City of Pismo Beach, 241 A.C.A. 316, 323, 50 Cal. Rptr. 402, 406 (1966) (imitiative cannot be used to prohibit tax levies). 
right or interest. ${ }^{130}$ At all levels, such measures must contain a declaration of the facts constituting the urgency and must be passed by an extraordinary vote-two-thirds of each house at the state level and four-fifths of the governing board or council at the local level. ${ }^{131}$ To the extent that the courts may refuse to review a legislative declaration of urgency, this restriction on the referendum is correspondingly greater than it necessarily would have to be.

In California, declarations of urgency by local legislative bodies have been freely reviewed and often struck down. ${ }^{132}$ This has occurred because the courts have read the statutes or charters involved as authorizing judicial review of the urgency determination, ${ }^{133}$ whereas at the state level the phraseology of the constitution, allowing the legislature to "deem" when a matter is necessary for the preservation of the public peace, health or safety, ${ }^{134}$ permits a contrary conclusion. ${ }^{135}$ While this

130 CAL. Const. art. IV, § 1 ( $(\pi 6$ ).

131 See statutes cited note 129 supra.

132 See In re Newell, 188 Cal. 762, 207 Pac. 371 (1922) (emergency citrus fruit shipping ordinance); In re Hoffman, 155 Cal. 114, 99 Pac. 517 (1909) (content of millk); County of Los Angeles v. City of Lawndale, $202 \mathrm{Cal}$. App. 2d 20, $20 \mathrm{Cal}$. Rptr. 363 (1962) (annexation of park property); In re Stratham, 45 Cal. App. 436, 187 Pac. 986 (1920) (reviewed but upheld); Rigdon v. City of San Diego, $30 \mathrm{Cal}$. App. 107, 157 Pac. 513 (1916) (ordinance allowing grant of liquor license).

133 See Davis v. County of Los Angeles, 12 Cal. 2d 412, 421, 84 P.2d 1034, 1040 (1938), citing Joplin v. Ten Brook, 124 Ore. 36, 42-43, 263 Pac. 893, 895 (1928); San Christina Invest. Co. v. City and County of San Francisco, 167 Cal. 762, 771-72, 141 Pac. 384, 387-88 (1914). In re Newell, 188 Cal. 762, 207 Pac. 371 (1922), apparently construed CAI. ELECT. CODE $\$ 3751$ (formerly Car. Pourmear Code $\$ 4058$ ) relating to counties as allowing broad judicial review of the urgency declaration. Since CAr. EIECT. CoDE $\$ 4050$ relating to cities is plrased similarly, a similar interpretation would be expected.

134 CaL. Const. art. IV, § 1 (ा 6).

135 See Davis v. County of Los Angeles, 12 Cal. 2d 412, 421, 84 P.2d 1034, 1040 (1938), citing Joplin v. Ten Brook, 124 Ore. 36, 42-43, 263 Pac. 893, 895 (1928). But certainly this conelusion is not compelled. CaL. Const. art. IV, \& 1 (II 5), referring to urgency measures, is phrased similarly to those provisions which have been held to allow review. See CAL. Exect. Code $\$ 3751$ discussed in note 133 supra. Cat. Const. art. IV, § 1 (II 6), to which Davis v. County of Los Angeles, supra, attributes much importance, may be seen as merely expanding the procedure to be followed in declaring a measure emergent-with no particular significance intended by the phraseology. Furthermore, some judicial review will be necessary for purposes of enforcing the prohibition against creating or changing offices and other privileges and rights (see text accompanying note 130 supra) in urgency measures. Nonetheless, the conclusion drawn by the courts is reasonable. Determining whether an emergency exists may be less withm the competence of a court than determining whether a measure creates an office, and so it is not necessarily inconsistent for a court to have the one power and not the other. The provision requiring a statement of the facts constituting the necessity may be seen as implying that the courts may review the statement (see note 145 infra and accompanying text) or, alternatively, as merely providing a means by which the voters might judge the propriety of the legislative determination. See, however, text following note 144 infra. 
distinction made on the basis of phraseology may be disputed, ${ }^{180}$ it nevertheless will, in most cases, allow the courts a freer review at the local level of government where the public may be in greater need of such protection. ${ }^{137}$ Such review is certainly more consistent with preservation of the referendum power against efforts of a local legislative body to avoid it.

The statewide rule, which is decidedly more restrictive, was enunciated in Hollister v. Kingsbury, ${ }^{138}$ and restated as dictum in Stockburger ข. Jordan:139

[T] he determination of the existence of a public necessity for the enactment of an urgeucy measure rests upon the judgment of the Legislature. It is . . . a legislative question, the determination of which will not be interfered with by the courts, save in those few exceptional cases where it appears clearly and affirmatively from the Legislature's statement of facts that a public necessity does not exist. ${ }^{140}$

This rule was adopted and applied in Davis v. County of Los Angeles ${ }^{141}$ which upheld the enactment of enabling legislation for school pension systems as an emergency measure in circumstances that might be said to have related to the public peace, health or safety. Hollister upheld a measure designed to protect oil and gas on state tideland property where there was clearly a threat to state property but only the most tenuous of links to the "public peace, health or safety." Hence the courts have been extremely reluctant to interfere with state legislative determinations of emergency and have often appeared to embrace the Oregon rule stated in Kadderly $v$. Portland, ${ }^{142}$ which stands for no review whatsoever. ${ }^{143}$

The Kadderly rule is undesirable when protection of the referendum is considered. ${ }^{144}$ The argnments that the two-thirds vote requirement and the ultimate responsibility of the legislators to the public at the polls are

136 See note 135 supra.

137 Many political scientists would no doubt concur that corruption in government is a greater threat at the local level. Some of the cases cited in note 132 supra at least suggest some overzealousness.

138129 Cal. App. 420, 425, 18 P.2d 1006, 1008 (1933).

13910 Cal. 2d 636, 642, 76 P.2d 671, 673-74 (1938) (issue was whether duties of officer had been changed).

140 Ibid.

14112 Cal. 2d 412, 422, 84 P.2d 1034, 1040 (1938).

14244 Ore. 118, 146, 74 Pac. 710, 721 (1903). The Kadderly rule has been modified in Oregon with regard to local legislative bodies but remains the same as to acts passed by the state legislature. See Joplin v. Ten Brook, 124 Ore. 36, 40, 42, 263 Pac. 893, 895 (1928).

143 See Davis v. County of Los Angeles, 12 Cal. 2d 412, 420-21, 84 P.2d 1034, 1039 (1938); Stockburger v. Jordan, 10 Cal. 2d 636, 642-43, 76 P.2d 671, 673-74 (1938) (citing Oregon case); Hollister v. Kingsbury, 129 Cal. App. 420, 426, 18 P.2d 1006, 1008 (1933). 144 See generally Barnett, Judicial Review of Exceptions from the Referendum, $10 \mathrm{Car}$.

L. REv. 371 (1922). 
a sufficient protection against legislative abuse are unconvincing. Measures of doubtful einergent character are sometimes passed despite the extraordinary vote required. Further, it is unlikely that an occasional misuse of the power to declare a ineasure emergent would bring reprisals at the polls. Most citizens may be unaware of the abuse, whereas, if they had an opportunity to vote on it, they might well disapprove the particular measure. At the polls, the issue presented is not the worth of the ineasure but the impropriety of the abuse of power-an issue bikely to carry little weight in a campaign fought over many issues and personalities. Meanwhile, the legislature can avoid the referendum's check.

The Kadderly argnment based on the separation of powers doctrine also makes little sense in hight of judicial review of constitutional questions, the checks and balances theory, and the constitution's express requirement that urgency measures include a declaration of the facts constituting the emergency. Arguably this last requirement implies that the courts have the power to review the legislative declaration, ${ }^{145}$ but the Davis court was unwilling to interpret it this broadly. ${ }^{146}$

Althougln narrowly stated and applied, the California rule appears to strike a reahistic compromise between preserving the legislature's freedoin of action to protect state interests and protecting the public and the constitution from possible legislative abuses. This is particularly evidenced by the broad construction given the phrase "public peace, health or safety," especially in instances where it is not so much the vote which is sought but rather the delay in the implementation of legislation. ${ }^{147}$ At the same time, the rule would seem to have sufficient flexibility to permit a court to use it if a blatant abuse of the referendum were attempted.

In light of this restricted rule, an attack on the validity of an emergency declaration would have a better chance of success if it could be shown that the measure falls within one of those categories of measures specifically denied the emergency immunity. ${ }^{148}$ Stockburger $v$. Jordan ${ }^{149}$ struck down an emergency declaration which was found to create a

${ }^{145}$ Cf. San Christina Invest. Co. v. City and County of San Francisco, 167 Cal. 762, 772, 141 Pac. 384, 388 (1914).

${ }^{140}$ See Davis v. County of Los Angeles, 12 Cal. 2d 412, 422, 84 P.2d 1034, 1040 (1938): "[Q]uestions of fact, necessity and expediency are for the legislature. ... [T] he requirement for a statement of the facts constituting the necessity in emergency legislation does not modify the principle nor bestow upon the judiciary power to declare the declaration invalid unless it 'appears clearly and affirmatively from the legislature's statement of facts that a public necessity does not exist." "

147 See cases cited note 143 supra. Cf. Mueller v. Brown, 221 Cal. App. 2d 319, 34 Cal. Rptr. 474 (1963), discussed in text following note 63 supra.

148 See text accompanying note 130 supra.

14010 Cal. 2d 636, 644-48, 76 P.2d 671, 674-77 (1938). 
substantial addition to, and therefore a change in, the duties of a state official. ${ }^{150}$ On the other hand, the Davis case rejected a determined attempt to invalidate an emergency pension enabling measure on the grounds that it changed the duties of an officer and also created a vested interest in the school teachers. ${ }^{151} \mathrm{~A}$ number of cases dealing with local legislative enactments have expanded the law in this area, ${ }^{162}$ but the extent of the exemption of measures creating special privileges or vested rights or interests appears singularly unexplored.

\section{Additional Restrictions}

\section{Current Appropriations and Tax Levies}

"Tax levies or appropriations for the usual current expenses of the State" are specifically exempted from the referendum. ${ }^{153}$ No extraordinary vote is required and the particular measure may go into effect at any date provided by the legislature. ${ }^{154}$ This constitutional exemption applies at all levels, ${ }^{155}$ despite the contrary impression created by Election Code sections 3751 to $3753,{ }^{156}$ and except to the extent that a city charter may broaden the scope of the referendum. ${ }^{157}$

It is clear that appropriations must be for current expenses in order to qualify for the exemption, but whether tax levies must be for current expenses is an open question. While it has been assumed that tax levies would have to be for current expenses, ${ }^{158}$ the supreme court has indicated that this might not be the case and that it might be receptive to an argument that all tax levies are exempt. ${ }^{159}$ Taxes would appear to have a special impact that would bring voter reaction at a regular election;

150 The consequence of striking down emergency declaration is, of course, merely to delay the effective date of a measure and to make it subject to referral. See Stockburger v. Jordan, 10 Cal. 2d 636, 650, 76 P.2d 671, 677-78 (1933); Klassen v. Burton, 110 Cal. App. 2d 539, 243 P.2d 28 (1952).

151 Davis v. County of Los Angeles, 12 Cal. 2d 412, 423-24, 84 P.2d 1034, 1040-41 (1938).

152 See, e.g., Martin v. Riley, 20 Cal. 2d 28, 123 P.2d 488 (1942); Behneman v. AlamedaContra Costa Transit Dist., 182 Cal. App. 2d 687, 6 Cal. Rptr. 382 (1960); Klassen v. Burton, 110 Cal. App. 2d 539, 243 P.2d 28 (1952); Brown v. Boyd, 33 Cal. App. 2d 416, 91 P.2d 926 (1939); Morgan v. City of Long Beach, 57 Cal. App. 134, 207 Pac. 53 (1922). 153 Car. Const. art. IV, \& 1 ( $\mathbb{1} 5$ ).

154 Roth Drug, Inc. v. Johnson, 13 Cal. App. 2d 720, 726-30, 57 P.2d 1022, 1024-26 (1936).

155 See Geiger v. Board of Supervisors, 48 Cal. 2d 832, 836, 313 P.2d 545, 546 (1957) (county) ; Hunt v. City of Riverside, 31 Cal. 2d 619, 623-24, 191 P.2d 426, 428 (1948) (city). 156 See Geiger v. Board of Supervisors, supra note 155 at $836-39,313$ P.2d at 547-49, construing former Elections Code \$\$ 1651-53, presently \$§ 3751-53.

157 See note 40 supra and accompanying text. See also Geiger v. Board of Supervisors, supra note 155 , at 837,313 P.2d at 547 .

158 See, e.g., Hunt v. City of Riverside, 31 Cal. 2d 619, 623-24, 191 P.2d 426, 428 (1948).

159 See Geiger v. Board of Supervisors, 48 Cal. 2dl 832, 836 n.1, 313 P.2d 545, 547 n.1 (1957). 
hence it could reasonably be argued that the exemption excludes all tax measures-especially because of the burden that might otherwise be imposed on long range governmental action.

Whether the courts would look behind a legislative declaration that a tax or appropriation measure is designed to meet current expenses is also unclear. ${ }^{160}$ The arguments for and against review of urgency declarations would seem to be applicable to this question. ${ }^{101}$ An added consideration, however, might be the special competence of the legislature in this area. Since matters of taxation and budgetary planning depend upon facts peculiarly within the legislature's competence, the courts should perhaps give particular deference to a legislative determination that an appropriation or levy is for current needs, and upset the determination only when it is clearly erroneous.

\section{Procedures as Restrictions}

The procedures relative to circulation of petitions for initiating or referring measures could be so stringently created and construed as to impinge substantially upon these reserved powers. ${ }^{162}$ By and large, the courts have minimized this possibility. For example, a substantial compliance test is used when there are alleged deviations, such as a woman's use of her husband's given name in signing a petition, ${ }^{163}$ or the omission or incorrect designation of a precinct number, ${ }^{184}$ or the addition of the date of signing by someone other than the signer. ${ }^{105}$ In such cases the deviations are not substantial. But when a deviation is substantial, especially if it is one likely to mislead the public, such as an inaccurate title on a petition, ${ }^{188}$ the deviation will not be overlooked. ${ }^{187}$ The sub-

100 Compare McClure v. Nye, 22 Cal. App. 248, 250, 133 Pac. 1145, 1146 (1913) (appropriation held not for current expenses) with Gilbert v. Ashley, 93 Cal. App. 2d 414, 415, 209 P.2d 50, 51 (1949) (tax levy, declaration treated as conclusive). In a charter city, they might. See Atlas Hotels, Inc. v. Acker, 230 Cal. App. 2d 658, 41 Cal. Rptr. 231 (1964) (declaration reviewed).

101 See text following note 144 supra.

102 See Perry v. Jordan, 34 Cal. 2d 87, 92-94, 207 P.2d 47, 49-50 (1949) (single subject himitation broadly construed); Ley v. Dominguez, 212 Cal. 587, 299 Pac. 713 (1931) (sohcitor and voter eligibility, married woman's signature).

163 Ley v. Dominguez, supra note 162 at 598,299 Pac. at 717.

104 Id. at 596-97, 299 Pac. at 717.

105 See Boggs v. Jordan, 204 Cal. 207, 216, 267 Pac. 696, 699 (1924) (dicta).

100 See Boyd v. Jordan, 1 Cal. 2d 468, 474-75, 35 P.2d 533, 535-36 (1934).

107 See Myers v. Stringham, $195 \mathrm{Cal}$. 672, $235 \mathrm{Pac}$. 448 (1925) (ordinance to be amended not set out). See generally Comment, 70 Harv. L. Rev. 1077 (suggesting legislation to cope with misrepresentations). The practice of the courts of using for interpretative purposes the arguments submitted to the voters during the campaign is another possible safeguard against deception. See Beneficial Loan Soc'y, Ltd. v. Haight, 215 Cal. 506, 515, 11 P.2d 857, 860 (1932); Crees v. State Bd. of Medical Examiners, 213 Cal. App. 2d 195, 211, 28 Cal. Rptr. 621, 630 (1963). 
stantial compliance test also works in the government's favor as, for example, when a public official, not authorized to do so, gives proponents or opponents of a measure inaccurate information which detrimentally affects their campaign. ${ }^{168}$ The same is true where a court construes a title or summary prepared by the attorney general. ${ }^{169}$

A possible inroad on the initiative and referendum is the holding in Lawing v. Faull ${ }^{170}$ that a charter city may increase as well as decrease the percentage of signatures required in the constitution to qualify a petition. The district court of appeal found that the percentages specified in the constitution were, as to city elections, only temporary "until otherwise provided by law," ${ }^{171}$ and stated that whether a higher requirement would be an unconstitutional restriction on the reserved powers would depend upon the burden imposed in view of the particular city involved. ${ }^{172}$ What would be a permissible requirement in a smaller city might be prohibitive, and therefore an unconstitutional himitation, in a larger one.

Lawing opens the door for many cities to increase their signature requirements, but it is unlikely that there will be any wholesale use of the opportunity since the growing California population and electorate probably stiffens the requirement automatically. But what Lareing also suggests is that this same population growth may make a previously established percentage requirement in a large city subject to challenge where the population growth has significantly increased, in absolute terms, the burden of qualifying a petition. In this respect, Lawing may be seen as a significant step toward preventing procedural requirements from becoming a restriction-or a greater restriction ${ }^{173}$-on these reserved powers.

\section{Re-enactment of Defeated Measures}

The constitution requires that amendments to measures passed by the initiative be approved by the voters unless the measure waives the requirement. ${ }^{174}$ This eliminates the danger of a subsequent legislative act

168 See Simpson v. City of Los Angeles, 40 Cal. 2d 271, 253 P.2d 464 (1953).

169 See Perry v. Jordan, 34 Cal. 2d 87, 94, 207 P.2d 47, 51 (1949).

170227 Cal. App. 2d 23, 38 Cal. Rptr. 417 (1964).

171 CaL. Const. art. IV, § 1 (ा 19).

172 Cf., Ryder v. City of Los Altos, 125 Cal. App. 2d 209, 270 P.2d 532 (1954), applying a test of reasonableness in upholding Government Code $\S 34701.1$ (then Election Code $\S 1702$ ), which restricts the right of citizens to petition for dissolution of their city within two years of the date of incorporation. The section is apparently intended to protect a fledgling city government from the very type of harassment suggested in this case and, in the interests of setting an issue to rest, at least for a time, seems eminently reasonable. 173 See Casstevens, p. 3 suggesting that California's population growth has already restricted the initiative to wealthy or well-organized special interest groups.

174 Cas. Const. art. IV, $\S 1$ (T 9), quoted note 4 supra; CaL. Const, art. IV, $\S 1 \mathrm{~b}$. See notes 31 and 66 supra and accompanying text. 
vitiating the will of the people. However, there are two other situations in which this danger may exist. When an initiative is defeated at the polls, the question may arise whether the legislature can subsequently enact essentially the same law. Although the issue has apparently not been presented, the legislature should be free to do so-without having any special burden of showing changed conditions which might indicate the public would now vote differently. Any other rule might seriously hamstring the legislature and attribute too much meaning to the negative popular vote. The referendum would be available if the opposition forces which voted down the prior imitiative desired to utilize it. Furthermore, this seems to be a situation where a direct reversal of the public will expressed in the prior initiative vote would bring the political check of reprisals at the polls.

But what of a measure which is passed by a legislative body, then is challenged by a referendum and, because of the challenge, is either withdrawn or submitted to the people and disapproved in a referendum vote? Could the legislative body then re-enact the measure, thereby defeating the referendum or forcing the opponents of the measure to circulate petitions once again? If this could be done the whole referendum process would be for naught. Cahifornia Elections Code section 4052 protects against this danger at the city level. It specifically provides that measures withdrawn or defeated by referral cannot be re-enacted for one year from the date of repeal.

In applying section 4052 , the courts use a substantiality test-striking down the attempted re-enactment of a measure which is in all essential features identical to one which has been repealed. The greatest problem is to determine whether a measure is substantially different. Each case seems to turn on its own facts. In Martin v. Smith ${ }^{175}$ the court held that a purported repeal of a measure being attacked by a referendum was in fact a substantial re-enactment of the measure. Furthermore, it extended the one-year restriction on re-enactment created by Election Code section 4052 to imclude the period during which the measure is pending repeal or referral. Hence, a legislative body may not enact a measure which is alike in all essential respects to one pending referral. However, if the second measure is passed as an urgency measure, ${ }^{178}$ or perhaps as a tax levy, ${ }^{177}$ it would take effect. ${ }^{178}$ While the Martin case seems to indicate

175176 Cal. App. 2d 115, 1 Cal. Rptr. 307 (1959).

176 See In re Stratham, 45 Cal. App. 436, 187 Pac. 986 (1920) (alternative holding). See generally Note, 49 Coruss. L. REv. 705 (1949) (power of legislature to enact law on subject pending vote).

177 See notes 158-59 supra and accompanying text; Gilbert v. Ashley, 93 Cal. App. 2d 414, 209 P.2d 50 (1949).

178 Hence an additional argument for judicial review of urgency declarations may be 
that the courts will favor preserving the referendum power in close cases, In re Stratham ${ }^{178}$ and Gilbert v. Ashley ${ }^{180}$ provide the counterweight as cases in which the second measure was held to differ in substance from the first. Gilbert in particular suggests that the degree of difference which will be deemed sufficient may be exceedingly small.

Significantly, there is no prohibition comparable to section 4052 in the state constitution nor in the statutes relating to county referenda. ${ }^{181}$ If the situation covered by section 4052 arises on the state or county level, the courts could arguably fill this void by applying a test similar to the substantiality test used when treating the matter at the municipal level. A failure to fill the void would have a cripphing effect on the referendum power.

\section{Measures of Non-General Concern}

An additional restriction, which apparently has been applied only at the local level in California, excludes from the initiative and referendum matters of strictly local, as opposed to general, concern. ${ }^{182}$ Street improvements are the prime example. ${ }^{183}$ The theory of the exemption is partly that such matters concern only a small segment of the population, and that since the people affected will bear the tax burden for the improvement via special assessments, the general population ought not to be able to impose or to block such local innprovements. The exemption is also justified by the counter-principle which was first articulated in the context of street improvements:184 Allowing referral of decisions to make local improvements may too greatly burden the government in the exercise of essential functions.

Dictun in an early case suggested that this restriction might also apply at the state level. ${ }^{185}$ Massachusetts has a class of special laws which are exempted in this manner, as do one or two other states, ${ }^{180}$ but apparently no case has yet materialized in California to carry out this early prophecy. There are but a few cases on the matter at the local level.

the need to prevent such declarations from being used to achieve re-enactment of repealed measures before they are properly re-enactable. See text accompanying notes 129-47 stipra.

17845 Cal. App. 436, 187 Pac. 986 (1920).

180,93 Cal. App. 2d 414, 209 P.2d 50 (1949).

181 CaL. ELEcT. Code $\$ \S 3750-54$.

182 This rule has been partially codified as to cities. See CaL. Exect. Code $\$ 4057$.

183 E.g., Starbuck v. City of Fullerton, 34 Cal. App. 683, 168 Pac. 583 (1917); Chase v.

Kalber, 28 Cal. App. 561, 153 Pac. 397 (1915).

184 See notes 44-46 supra and accompanying text.

185 "At least it may be said that [the referendum] apples to all statutes enacting measures in which all citizens of the entire state are interested." Hopping v. City of Richmond, 170 Cal. 605, 609, 150 Pac. 977, 978 (1915) (dictum).

186 See Note, 3 Stax. I. Rev. 497, 505-06 (1951). 
Basically the exemption seems proper, but, as is so often the case, the difficulty is in applying the rule. An initiative measure to limit a city's power to acquire off-street parking facilities was kept off the ballot partly because off-street parking projects were said to be matters of local rather than citywide interest; ${ }^{187}$ but an amendment to a zoning ordinance, which would alter the classification of just one parcel of property, would be subject to the referenduni. ${ }^{188}$ Is the general power of a city to acquire parking facilities any less of a citywide concern? Because so many matters may be characterized as affecting only a segment of the population or a sub-area within the whole, the courts should avoid the facile extension of this exemption to the point where matters of legitimate concern to the general public might be taken out of the scope of the initiative and referendum.

\section{CONCLUSION}

In virtually all cases dealing with the imitiative and referendum-in determining the validity of initiative measures before they are enacted, construing statutes which would vest exclusive power in a local legislative body or impose a special procedure having the same effect, distinguishing between administrative and legislative acts, or reviewing urgency declarations-the courts have a great deal to say about the scope of these institutions. It is the opinion of this writer that the courts should adhere to their often repeated principle that the initiative and referendum provisions of the constitution should be broadly construed so as to maintain the maximum power in the people, and that they have a duty to protect these institutions from both direct attack and indirect subversion. On occasion, probably more througl inadvertence than by design, the courts have failed to do all that they inight. For the most part, however, they have acted commendably.

As the periodic assaults on the initiative and referendum arise and fade, it is hoped that the courts will resist urgings to use judicial powers to circumscribe these institutions. While the mitiative and referendum may not fit into a given philosopher's democratic model, and while these powers may, like any others, be misused from time to tinie, one would hope the courts will not fall prey to the elitist argument that the people do not know what is best for them and therefore need someone else to tell them. Pragmatically, the institutions work; like their representatives, the people may sometimes approve mischievous or unconstitutional

187 Alexander v. Mitchell, 119 Cal. App. 2d 816, 827, 260 P.2d 261, 267 (1953) (alternative holding).

188 See Johnston v. City of Claremont, 49 Cal. 2d 826, 834-36, 323 P.2d 71, 75-77 (1958); Dwyer v. City of Berkeley, 200 Cal. 505, 512-15, 253 Pac. 932, 935-36 (1927). 
measures, but by and large, as studies show, ${ }^{180}$ they are good legislators. In a society where government moves further and further from the people, these imstitutions can help keep it near. If an occasional "bad" measure is passed, let those who urge less democracy instead use the tools of democracy to convince the people of the "rightness" of their view. While the courts have the duty to maintain these institutions within their proper boundaries, they should not be the vehicle for any constriction of those boundaries.

Donald S. Greenberg

189 Crotch, The Inttiative ard Referendum in Caldfornta (1950); Radin, Popular Legislation in California: 1936-1946, 35 CarTr. L. Rev. 171 (1947). 